\title{
Challenging an arbitration award: some key principles
}

by Khawar M Qureshi

Since the introduction of the Arbitration Act 1996, the restrictive approach adopted by the High Court in reviewing the arbitral process has been confirmed in the very limited number of cases which have been presented by parties thus far.

$\mathrm{T}$ he rationale of the Arbitration Act 1996 ("the 1996 Act") is to place firmly at the core of any review of the arbitral process the overriding objective to give effect to party choice (arbitration as opposed to court), and the need for finality. Accordingly, the circumstances in which the jurisdiction of the English Court can be invoked are very clearly and restrictively circumscribed by the 1996 Act.

In this article we will consider two issues which illustrate the difficult balancing exercise which the court is required to engage in:

1. What are the principles governing an application to seek permission to challenge an arbitration award on the grounds of an error of law?

2. What are the principles governing an application to seek an extension of time to challenge an arbitration award?

We shall examine these two issues with references to three cases:

(i) CMA CGM S.A. and Beteiligungs-Kommanditgesellschaft MS and others ("CMA"), 18 December 2002 (Transcript) (Court of Appeal).

(ii) Aoot Kalmneft and Glencore International $A G$ and another ("Aoot”) 27 July 2001 (Transcript) (Coleman J).

(iii) Westminster Oil \& Gas Ltd and Barmico Shipping Limited (“Westminster") 10 March 2003 (Unreported/ Transcript) (Tomlinson J).

\section{ERROR OF LAW}

The previous statutory test was contained in section 1 of the Arbitration Act 1979 which had been interpreted by the House of Lords in the cases of Pioneer Shipping $v$ BTP Tioxide ("the Nema") [1982] AC 724 and Antaios Compania SA $\checkmark$ Salen AB ("the "Antaios") [1985] AC 191. In essence, no appeal was to be entertained unless it could be shown from a perusal of the award that the arbitrator was either "obviously wrong" (where interpretation of a "one-off" clause was involved), or a "strong prima facie case had been made out that the arbitrator was wrong" (where interpretation of a standard term provision was required or an issue of general public importance was involved). The guidance of the House of Lords is commonly referred to as the "Nema guidelines" and this has to a large extent been given statutory effect under the 1996 Act.

Section 69(3) of the 1996 Act ("Section 69(3)") provides the present test and states as follows:

“(3) Leave to appeal shall be given only if the court is satisfied -

(a) that the determination of the question will substantially affect the rights of one or more of the parties,

(b) that the question is one which the tribunal was asked to determine,

(c) that, on the basis of the findings of fact in the award -

(i) the decision of the tribunal on the question is obviously wrong, or

(ii) the question is one of general public importance and the decision of the tribunal

is at least open to serious doubt"

In the CMA case, the Court of Appeal made forceful observations, inter alia, as to the need to keep written submissions short and focussed (given that most applications pursuant to s 69(3) are dealt with on paper), as well as expressing its desire that High Court Judges should be slow to grant permission to appeal from their decisions to the Court of Appeal.

In the CMA case, three eminent commercial arbitrators had to consider whether a "war-cancellation" clause in a standard form charterparty had properly been invoked due to the involvement of Germany in the NATO-led Kosovo intervention in March 1999. Tomlinson J refused permission to appeal and gave short written reasons for doing so (in line with the decision of the Court of Appeal in the case of North Range Shipping Ltd v Seatrans Shipping Corporation [2002] 1 WLR 2397). 
Nevertheless, His Lordship held that the proper interpretation, scope and effect of the war-cancellation clause was a question of general public importance, in respect of which he would grant permission to appeal to the Court of Appeal.

The Court of Appeal held that permission to appeal should not have been granted by Tomlinson J, as the arbitrators had unanimously agreed that, whatever the true interpretation and effect of the war-cancellation clause, it could not have been properly invoked due to the passage of time. However, on the question of whether a state of "war" existed, there was a disagreement between the arbitrators. Sir Christopher Staughton delivered his minority view that the state of "war" existed in Kosovo at the material time. The Court of Appeal examined that issue, and also considered whether the Nema guidlelines had been affected by section 69 (3)(c) (ii), in the context of interpretation of standard term contracts and issues of general public importance.

It was held by their Lordships that the old test which required a judge to be satisfied that, on issues of general public importance (such as construction of standard terms in a contract) " a strong prima facie case had been made out that the arbitrator had been wrong in his construction" had now been expanded, albeit very slightly. The new test required that "the question should be one of general public importance and the decision of the arbitrators should be at least open to serious doubt" (emphasis added).

In the CMA case, the fact that there was a divergence of opinion between the highly respected arbitrators on the issue of the proper approach to the "war" issue was held by their Lordships to satisfy the new test. However, because (in the unanimous view of the arbitrators) the passage of time meant that no war cancellation clause could have been invoked, the question was purely academic and its determination could not affect the rights of the parties. Permission to appeal to the Court of Appeal was therefore unnecessary. The Court of Appeal did however acknowledge that Tomlinson $\mathrm{J}$ had effectively granted permission to appeal to enable the Court of Appeal to deliver guidance on the new appeal regime. Given the conspicuous absence of recent authority on this point, the Court of Appeal's decision in this case deserves close study.

\section{EXTENSION OF TIME}

The 1996 Act contains strict time limits for applications to court. Section 70 of the 1996 Act stipulates that a challenge under section 67 (substantive jurisdiction), section 68 (serious irregularity) and section 69 (point of law) must be brought within 28 days of the date of delivery of an arbitral award. There is jurisdiction for the Court to grant an extension of time, as provided for by section 80(5) of the 1996 Act and CPR 3.1.2. The approach of the Commercial Court to applications for an extension of time has been illustrated by two cases which we shall consider below:

\section{The Aoot case}

Coleman J was asked to grant an extension of time to enable challenges to be made to an award on jurisdiction. The award had been made between two foreign parties in the context of an agreement for the supply of crude oil. Applications were made to the court pursuant to sections 67 and 68 between 11 and 14 weeks respectively after the expiry of the 28 day time limit. Coleman J conducted a full review of the principles to be applied by the court when considering whether to grant an extension of time. Party autonomy and finality of awards, together with avoidance of unnecessary delay and expense, needed to be weighed against avoidance of a substantial injustice.

His Lordship held that it was important for the courts not to indulge parties that were dilatory by granting extensions of time, as this would impact upon the desirability of English arbitration clauses being incorporated by foreign parties who were looking for speed and certainty. However, in the case of relatively unsophisticated foreign parties, it might be expected that they move with less speed than more experienced entities. In that regard, his Lordship set out the factors which the court should consider when faced with an application for an extension of time. These are as follows (as per para 59 of the judgment):

"(i) The length of the delay

(ii) Whether, in permitting the time limit to expire and the subsequent delay to occur, the party was acting reasonably in all the circumstances;

(iii) Whether the respondent to the application or the arbitrator caused or contributed to the delay;

(iv) Whether the respondent to the application would by reason of the delay suffer irremediable prejudice in addition to the mere loss of time if the application were permitted to proceed;

(v) Whether the arbitration has continued during the period of delay and, if so, what impact on the progress of the arbitration or the costs incurred in respect of the determination of the application by the court might now have;

(vi) The strength of the application;

(vii) Whether in the broadest sense it would be unfair to the applicant for him to be denied the opportunity of having the application determined."

In the Aoot case, the applicants had delayed for almost three months before commencing their applications. The delay was asserted to be due to ignorance of time limits, which in turn was attributable to their failure to take English legal advice. Coleman J considered this to be "totally unreasonable". Moreover, the challenges being made were bound to fail. The applications for extensions of time were refused accordingly. 


\section{The Westminster case}

This case concerned a claim for monies allegedly due under the terms of a charterparty. A challenge was brought to the award of the sole arbitrator five weeks after the expiration of the 28 day time limit, on the basis of sections 67 and 69. The applicant contended that the arbitrator had no jurisdiction to consider the issues placed before him, because any claims arising under the charterparty had been the subject of a novation. The applicant contended that this had the result, inter alia, that the arbitration provision could not be invoked against it.

Tomlinson J considered the issues in the context of the approach set out in the Aoot case. The delay of five weeks was considered to be "totally inexcusable". Nevertheless, the applicant was granted permission to challenge the award on the basis of lack of substantive jurisdiction (s 68) and error of law (s 69) on terms.

In the Westminster case, the court was satisfied that the basis for the challenges had been made out with sufficient strength to merit consideration at a full hearing. From a practical standpoint, a comparison of the court's approach in the Aoot and Westminster cases shows considerable consistency. The key factors are the length or delay and its reasons, the merits of the substantive application and the balance of prejudice to the parties.

\section{CONCLUSION}

The cases identified above indicate that the High Court's gates are tightly controlled when parties who have decided to arbitrate attempt to invoke the supervisory jurisdiction of the court. It would appear that the High Court is likely to open those gates where it needs to settle important and unresolved questions of law, or where there is a serious risk of substantial injustice being caused.

\section{Khawar M Qureshi}

Barrister and Treasury Counsel 